\title{
The American Attitude Towards Albania During the Peacemaking in 1919
}

\author{
Rovena Vora \\ Ph.D., Lecturer at the Department of English language, \\ Faculty of Foreign languages, University of Tirana, Albania
}

\section{Abstract}

The American attitude towards Albania played an important role during the peacemaking at the Paris Peace Conference in 1919. The United States, unlike the European nations, entered the conflict without interests or policy toward Albania. Before the entry of the United States into the First World War there had been no American policy towards Albania and it had never been recognized by the United States. It was only after America's entry into the world struggle that an American attitude toward the Albanian problem began to develop. More concretely, it was in the Inquiry, an organisation which was to begin preparations for the peace settlement, that an American policy towards Albania began to form. Unfortunately, before the Paris Peace Conference the plans of the American experts for a solution to the Albanian problem were similar to the Albanian settlement outlined in the Treaty of London. On the eve of the Peace Conference, the American position became more favourable to Albania. During the negotiations the United States supported the integrity of Albania within its 1913 frontiers and refused to allow this small country to be partitioned further. President Woodrow Wilson and ex-President Roosevelt united in sympathy for the Albanian cause. The Albanians are deeply grateful to them for leading the way in the defense of their just cause. The Albanian problem during the peacemaking brought Albania to the foreground and its name appeared in big headlines on the first page of the American newspapers at that time, helping a large section of the American public to locate Albania.

Keywords: President Wilson, Albanian problem, peacemaking, borders, Vatra

\section{Introduction}

Albania is a small country, part of the Balkan Peninsula, with a population which has dwindled to three million and possesses harbors and a seacoast that runs parallel to that of Italy on the Adriatic Sea. Being descendents of the ancient Illyrians, the Albanians are the oldest race in Europe to survive upon the land where the light of history found it, and the tenure of their land has been made possible only by a long, 
brave struggle. For centuries it has gone through heroic struggles against the unspeakable Turks and by paralleled invasions and counterinvasions during the terrible wars. They have always survived the shock, have survived the burning of their villages, the wasting of their lands, the massacres of their people and emerged somehow unbroken, unassimilated through centuries. The geographical position of Albania has played a great role in the destiny of its people. Albania became nominally a province of Turkey in 1468 and remained such until 1913, when the London Conference granted a national independence under a prince chosen by the Great Powers. The Albanians bitterly complained at that time about the borders delimited for them on the ground that many purely Albanian districts had been given to Montenegro, Greece and Serbia.

At the beginning of the twentieth century, during the peacemaking, the division of borders among the Balkan countries brought Albania to the foreground and for the first time since the Balkan wars its name appeared in headlines on the first page of American newspapers. This helped a large section of the American public to locate Albania. To many Americans, the name of Albania sounded very much like that of Armenia. These two different countries belong to two different continents and are inhabited by two different races speaking different tongues. Armenia is situated on the easternmost part of Asia Minor near the Black Sea, while Albania is to be found on the westernmost part of the Balkan Peninsula, perched on the cliffs of the Adriatic Sea and overlooking Italy. The Albanians have lived under such conditions that they were not permitted to make themselves and their true situations known to the west. It was due to a great extent to the Albanians living abroad, especially the Albanians living in America through the organization "Vatra" with its headquarters in Boston, Massachussetts that Albania was granted independence at the London Conference in 1913.

Some years later, on July the $4^{\text {th }}, 1918$, two of the most illustrious names in America and in the whole world were added to the list of friends of Albania. On that day, representatives of all racial groups in the United States were invited to accompany President Woodrow Wilson for the celebration of Independence Day at Mount Vernon. The Albanian representative was Rev. Fan S. Noli, then president of the PanAmerican federation "Vatra". On the return trip from Mount Vernon aboard the presidential yacht, Mayflower, the Albanian representative had an occasion to state informally the case of Albania before President Wilson, appealing to him for its restoration. President Wilson listened to his plea with a benevolent interest, assured him of his sympathy and expressed his solemn determination to help Albania. In his famous speech on peace conditions President Wilson declared that the independence of all the Balkan nations should be restored along racial and historical lines and guaranteed by international agreement.

The Albanians living in Albania and abroad believed in President Wilson and were fully convinced that America and its allies would do justice to each and all small 
nationalities struggling for national freedom and thus establish peace on a sound basis. Even ex-President Roosevelt, in a public statement of American War claims on the same day included Albania in the list of the countries, whose independence must be restored and placed under the guarantee of the Allied powers. The following message was sent by Colonel Roosevelt to the Albanians through Rev. Fan S. Noli: "The independence of Albania must be restored at the next Peace Congress and put under a disinterested guarantee by the Allied Powers. I shall do anything in my power for the achievement of that result and for the recognition of the just claims of the ancient and brave Albanian race" (Adriatic Review, p. 8). It is highly significant that two such great American leaders like President Woodrow Wilson and ex-President Colonel Roosevelt unite in sympathy for Albania.

\section{Methodology and Discussion}

In presenting this theoretical approach I have tried to combine historical facts from different sources, like various press reports, official documents as well as publications at home and USA by experts and politicians. This study constitutes one of the few scholarly publications dedicated exclusively to the American attitude during the peacekeeping. The Albanian people have always had strong feelings of sympathy and friendship for the American people and government. US foreign policy towards Balkan countries had oscillations at different periods of time depending on the American internal political relations. The historical relationship between Albania and US has been an elongated journey since the beginning of the twentieth century. Being a small and a newly independent country constantly under various threats by neighbouring countries, the Albanians at home and worldwide placed high hopes in the support and protection of the Unites States after the end of the First World War. The Albanian question at the Paris Peace Conference is characterized by three important phases in American foreign policy (Hadri, 2018):

1. The period before the Peace Conference - this is distinguished by vague and undecided attitude of the American administration towards the Albanian question, though relying on general international principles established by President Wilson.

2. Defensive period of the Albanian state by President Wilson and by the negotiating USA delegation during all deliberations at the Paris Peace Conference;

3. The period after Wilson, a new hesitating position of the new American administration and its initial pondering in the negotiations of the Albanian state.

The American attitude towards Albania was to play an important role during the peacemaking. The United States entered the conflict without interests in Albania or policy toward this nation. Before the entry of the United States into the first World War there had been no American policy towards Albania. This new principality, only created in 1913, had never been recognized by the United States. And Albania's shaky 
autonomous existence quickly ended in 1914 before any American position developed. It was only after America's entry into the world struggle that an American attitude toward the Albanian problem began to develop. After the American declaration of war, President Wilson created an organization, the Inquiry, which was to begin preparations for the peace settlement. This organization, composed of members from the academic and Liberal establishment, was to prepare plans for a lasting peace based on "scientific" (apolitical) principles. And it was in the Inquiry that an American policy towards Albania began to form.

By the end of 1917, an initial report was prepared by the Inquiry which included tentative conclusions about the Albanian problem. This early report recommended that "an independent Albania is almost certainly an undesirable political entity." The rationale for this position was primarily economic. This first proposal, like those of subsequent Inquiry reports, was opposed to the goals of Albanian nationalists. Following this report, a "scientific" investigation for the Albanian problem was conducted which included academic reports, interviews with the Albanian nationalists in the United States, and talks with the Allied experts. When the final report of the Inquiry was prepared in January 1919 there had been some changes. The plans of the American experts for a solution to the Albanian problem was similar to the Albanian Settlement outlined in the Treaty of London. The Inquiry report suggested that while an autonomous Albania should continue to exist, parts of northern Albania should be given to the new state of Yugoslavia and in southern Albania both Gjirokastra and Korytsa, should be annexed by Greece.

A closer examination of this report reveals a mixture of economic, ethnic, and strategic reasoning behind the conclusions of the American experts. The major reason the Americans wished to give northern Albania to the Yugoslavians was to enable them to develop Shkodra as an important Adriatic seaport. The Albanians were thought to be incapable of such economic development. Besides, the Americans believed that by joining northern Albania would be united with Albanian mountain tribes in Montenegro and western Serbia. This plan also included certain economic advantages. The 1913 boundary has often separated a pastoral tribe from its summer or winter pastures, forcing it to cross a national frontier annually. Giving northern Albania to Yugoslavia would keep national boundaries from interfering with these seasonal migrations. But the ethnic hatreds in the region complicated this proposal. Because there was a history of warfare and hatred between Serbians and the Albanians, northern Albania should be given to Yugoslavia as a mandate under the League of Nations, which would protect the rights of Albanians. The American experts predicted that in the course of time, northern Albanians would be absorbed into the Yugoslavian population. According to the American plan, Albania would lose Shkodra, 9, $800 \mathrm{~km}$ of territory, and 275, 000 of population to Yugoslavia.

The American experts also planned to adjust Albanian's boundaries in the south. Part of southern Albania, around Gjirokastra and Santa Quaranta would be given to Greece 
for ethnic reasons. Greece would also receive the Korytsa region in Southeastern Albania, even though the population was largely Albanian. This violation of national self-determination was also justified by economic and strategic arguments. The Greeks would be given southern Albania in full sovereignty because of southern Albania's strong Hellenic inclinations and because of the success of the Greeks in assimilating Albanians in the past. The Albanian area to be assigned to Greece would include 2.400 square miles and about 250.000 inhabitants (Woodall, 220).

What to do with the remaining area of Albania was a difficult problem for the Inquiry. Because of the political immaturity of Albanians, the American experts felt it necessary to give central Albania nominal independence as a mandate under the League. The obvious choice to hold such a mandate was Italy. But the Americans feared Italian influence in the region. Since no other nation would agree to take the Albanian mandate, the Americans were faced with either giving the mandate to Italy, against their judgment, or allowing the Albanians to rule themselves, which was also against their judgment. Because it saw no solution to the problem, the Inquiry refused to make a recommendation on what to do with central Albania. It did agree, however, that Italy should obtain a temporary mandate over Vlora. No reasoning was given for this recommendation, but obviously the Inquiry acknowledged Italy's strategic need to control the entrance to the Adriatic and almost certain obtainment of this goal. Even in this concession the American experts were planning to offer Italy less than the full sovereignty it expected to obtain in Vlora.

The recommendations of the Inquiry were admittedly experimental and tentative, especially in regard to boundaries. But one element was clear and would remain part of America's Albanian policy throughout 1919. It was felt that the Albanian people were not prepared for full independence. The project of a united Albania appears impracticable to them. The weakness of national feeling among the people, the disruptive forces that spring from backward political institutions, the difficulties of communication, the intrigues of neighboring states-all these are obstacles which can be faced only under the protections, of a Great Power (Woodall, 226). The suggestions of the Inquiry to reduce radically Albanian's territory and population were not followed by the American negotiators in Paris. The "scientific", mainly economic, proposals of the Inquiry were softened by a stricter allegiance to Wilsonian selfdetermination. Pastorelli in his book "L'Albania" suggested that the American delegation decided against the Inquiry's recommendations after talks with Harold Nicolson of the British delegation, and the American delegates quickly came to respect the opinions of Aubrey Herbert and British Albanophiles. Furthermore, President Wilson, while giving the American delegation no instructions on the Albanian problem, insisted that any violation of self-determined should be reported to him and justified. Also, the Albanian delegations, including delegates supported by AmericanAlbanian organizations, may have helped to alter the anti-Albanian position of the Inquiry report. 
On the eve of the Peace Conference the American position had become more favorable to Albania. During the negotiations the United States supported the integrity of Albania within its 1913 frontiers, except for the cession of Gjirokastra district to Greece and Vlora region to Italy. Throughout the negotiations the Americans refused to allow Albania to be partitioned further. However, the Americans never suggested that Albania should be allowed independence without becoming a mandate under the League. Although there was some discussion of the United States becoming the mandatory power it quickly became evident that that was not possible and that Italy would receive the mandate. However, the American delegation always considered it a great concession for Italy to receive the Albanian mandate and always insisted that this mandate should limit considerably Italy's power over Albania. The American negotiators held this position long after it became evident that the Italians, like the other Great Powers, had no great desire to be burdened with such a mandate. But during the opening sessions of the Greek Committee, the United States would work with Italy to support the integrity of Albania, except for Gjirokastra.

The President of the United States, Woodrow Wilson, on several occasions pronounced important speeches inspired by the most noble sentiments of humanity. The principles which he at first proclaimed were gradually affirmed, enlarged in their scopes and developed till they represented all the force of the great President's personality, drawing strength from the decisions of the Republic and from the firm persuasion of the whole would that they were in harmony with the sincerity of the sentiments from which they derived. As mentioned earlier, in the speech which the great President pronounced on the $4^{\text {th }}$ of July 1918 on the tomb of Washington, he laid down in clear, firm and decisive terms the principal points, which would constitute the keystone of the Albanian question. He spoke as follows: "the settlement of every question whether of territory, of sovereignty, of economic arrangement or of political relationship upon the basis of the free acceptance of the settlement by the people immediately concerned, and not upon the basis of the material interest or advantage of any other nation or people which may desire a different settlement for the sake of its own exterior influence or mastery" ("The Adriatic Review", 62).

After that speech, congratulations poured on the President from all quarters together with statements of political men, public bodies, and private citizens. Wilson tried to maintain his promises throughout the stages of the Peace Conference. He emphasized that he opposed the division of Albania even as mandates, since such a division would make the eventual independence of Albania more difficult. Wilson added that giving Albania to Yugoslavia or Italy was as bad as giving Yugoslavia to Italy or vice - versa. In fact, throughout the history of the Albanian problem during the peacemaking, Albania had been a part of the Adriatic question. The leaders of England, France and Italy had agreed to solve the Adriatic question by partitioning Albania. Wilson's response finally put an end to this approach, and the Albanian problem was finally separated from the Adriatic question. Faced with few alternatives, Albanian lands could not be bargained anymore for concessions to the neighbour countries. Although 
Wilson's interference had temporarily prevented the partition of Albania by the Great Powers, the American President had not settled the problem of what to do with Albania. During 1920, since Albania was no longer useful to them as a bargaining chip, the English, French and Italians continued to withdraw their occupying forces, leaving Albania vulnerable to foreign intrigue, invasions and anarchy. Faced with the indifference of the Great Powers, the Albanians were forced to defend themselves against foreign armies.

\section{Conclusions and Recommendations}

The Albanian problem was not, however, confined to the meeting rooms and hotels of Paris. A study of the problem must examine local events within that country. Albania was occupied by foreign troops, its neighbors were mobilized on her ill-defined borders, and guerilla bands roamed the country. While Italy and the United States supported recognizing Albania's pre-war frontiers, Great Britain and France insisted on the partition of Albania, as provided by the Treaty of London (1915), unless Italy was willing to make concessions elsewhere. Albania's future was contingent on territorial transfers in the Adriatic and Asia Minor. While the peacemakers wasted 1919 in unsuccessful attempts to settle the Adriatic question and to divide of Asia Minor, events occurred within Albania, which would affect the solution of the problem.

\section{References}

[1] "The Adriatic Review" (1918-1929). 97 Compton Street, Boston, Massachusetts.

[2] Bland, William; Prica, Ian (1986): "A tangled web; A story of Anglo- American Relations with Albania (1912-1955)". London.

[3] Çami, Muin (1970): "Kongresi i Lushnjes dhe Lufta e Vlorës". Studime Historike.

[4] Çami, Muin: "Lufta e popullit shqiptar për çlirim kombëtar". Akademia e Shkencave. Instituti i historisë".

[5] Çami, Muin: "Shqipëria në marrëdhëniet ndërkombëtare 1914-1918". Akademia e shkencave. Instituti i historisë.

[6] Çami, Muin (1996): "Shqipëria në Konferencën e Paqes në Paris në 1919”. Studime historike.

[7] Hadri, Arbër (2012): "Presidenti Villson dhe çështja shqiptare: Politika e SHBA në Konferencën e Paqes në Paris 1919-1920". Prishtinë: Instituti i Historisë - Ali Hadri.

[8] Hadri, Arbër (2018): "The emerging US-Albanian Relations and Kosovo issue". International Journal of Humanities and Social Sciences. Doi:10.30845/ijhss.v8n7p7. 
[9] Heckscher, August (1987): “Woodrow Wilson”. Washington D. C. ICMA. [10] Knopf, A. (1993): "The twentieth century. A brief global history". New York.

[11] Link S., Arthur (1979): "Woodrow Wilson, Revolution, War and Peace". Harlan Davidson, Illinois.

[12] Milo, Paskal (1991): "Shqipëria dhe Jugosllavia”. 1918-1927. 8 Nëntori.

[13] Silajxhiç, Haris (1999): "Shqipëria dhe SHBA në arkivat e Washingtonit". Dituria.

[14] Woodall, R.L. (1978): “Albanian problem during peacemaking, 1919-1920”. Memphis State University. 